\title{
Sweden's view of development science
}

Sweden devotes a larger fraction of its gross national product to foreign aid than almost any other member of the United Nations, so it has taken its contribution to the forthcoming United Nations Conference on Science and Technology for Development very seriously. Wendy Barnaby reports

SWEDEN is finishing preparing its national report on the role of science and technology in development which, with the other 148 United Nations members' national reports, will be circulated in preparation for next year's United Nations Conference on Science and Technology for Development (UNCSTD). Inundated as they will be, few delegates will bother to read any given report. This is a pity, for Sweden is bending over backwards not to preach. Its report is a plea for 3 particular outlook on science and society. And its starting point is what it has learned about the role of science and technology in its own development.

The main concern is that UNCSTD should not degenerate into a discussion of the difficulties of various technological fixes that have been exported to Third-World countries. Sweden would like to see the conference deal more widely with development problems, and the ways science and technology interact with them. It hopes for more awareness of the way science and technology affect the whole process of development. So, drawing on its own experience, it calls attention to what has to happen in any society before research and development can find a footing there: political decisions must be made to start $\mathbf{R} \&$ D; specific sums must be allocated to specific projects by officials in an organised way; trained scientific personnel must coordinate their labour to carry out the projects; and the scientists must have been produced by an educational system anchored in the local culture.

Sweden sees science and technology as one link in this chain (cultural values-educational system-scientifictechnological infrastructure-bureaucrats-politicians), and stresses that all the links affect each other. So if any country is suddenly injected with a certain sort of technology, for instance, there will be consequences for all the other aspects of that society, not merely for its technological mix.

According to Mr Lennart Baage, of the Foreign Ministry's Office for International Development Cooperation, the national report will make some general proposals in keeping with this outlook. A summary of the report makes various suggestions for establishing efficient R\&D in any society: that bodies in the central state administration should be created to stimulate and plan for R\&D; that results should be given a means of application through an infrastructure, built up from an education system; that $R \& D$ resources should be devoted to priority areas relevant to social goals; that the development of a domestic capacity for technological evaluation may be an important step towards self-reliance; that the pace of structural transformation historically associated with development in industrialised countries

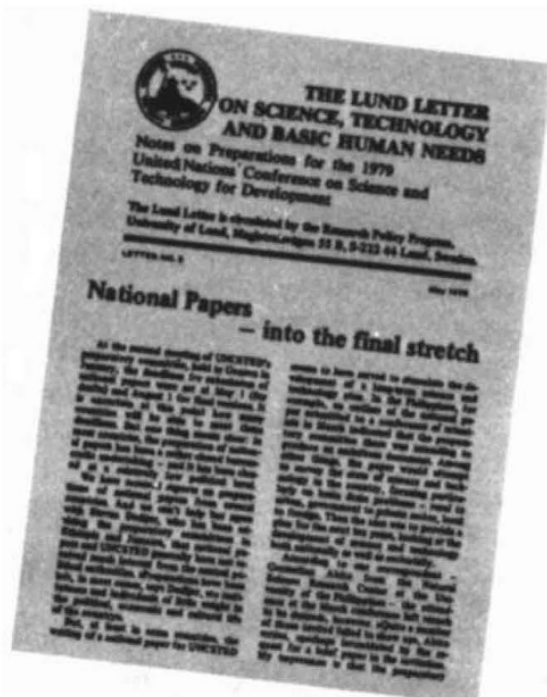

should, if possible, be avoided in the Third World; and that goals for major R\&D projects should be clearly specified so that the success of the projects can be judged.

The summary says that development should be supported first in the poorest countries, on an international level, and urges better coordination of science and technology within the UN system and a clearer division of responsibilities between the agencies involved. Baage says that no proposals for specific countries will be made before Sweden has heard what various ThirdWorld countries themselves have to say.

UNCSTD is being treated with customary Swedish solemnity. A lot of (also customary) hard work is going into the preparations. The national report was arrived at by subjecting various commissioned studies for review by a panel of representatives from several interested bodies. It carefully defines the concepts of 'science', 'technology' and 'development' before elaborating on the Swedish outlook. Its pedantry, logic and pleas for a holistic approach must seem a luxury to the Third World. Yet the Swedish view has resulted not only from domestic experience, but also from attempts to get to grips with some of the problems facing scientists in developing countries.

The largest umbrella for these attempts is the Swedish Agency for Research Cooperation with Developing Countries-SAREC. One of the institutes it supports is the International Foundation for Science (IFS), also based here. This small group gives grants to young scientists from developing countries on the conditions that their work is relevant to the needs of their country and carried out in it or some other part of the Third World. This year, IFS is dividing about \$1.3 million between 250 projects. Sweden supplies half of its budget, and the rest comes from state grants from eight industrialised countries and one developing one-Nigeria. More research with an eye to the Third World is being done through the international seminars in physics and chemistry at the University of Uppsala. Each year, the seminars give grants to 30 young thirdworld scientists who must have been employed by a university in their home country for at least one year: this stipulation being an effort to stop the brain drain. The Fellows join a Swedish research group in their field of interest. About $90 \%$ of the Fellows are still active in their home countries several years after having been maintained by the contacts and visits that the Swedish researchers are generally able to keep up with them.

According to one study done for the national report, about a third of Sweden's approximately 900 research institutes are doing research which they judge to be of direct interest to developing countries, although only about $10 \%$ actually cooperate with the Third World. About 400 projects were cited as being directly relevant to developing countries: $42 \%$ are in the social sciences and humanities (mostly related to Asia); $22 \%$ in medicine (mostly related to Africa); $17 \%$ in mathematics and natural sciences (again mainly related to Africa) and $10 \%$ in agriculture, forestry and veterinary science (with Africa slightly more popular than Asia).

There is a lot of research being done in Sweden which could possibly be useful to the Third World. This may not be surprising given recent estimates that $62 \%$ of world R\&D resources are spent within OECD countries, $34 \%$ within Comecon and only $4 \%$ within developing countries, where even this miniscule amount is concentrated in only a few. But how are developing countries assured access to research that could help them, given 
that it is practically always done in industrialised countries? This is one of the subjects to be taken up at a conference in May and June organised by the research policy programme at the University of Lund. Created in the late 1960s to study questions of science and technology policy, the research policy programme has focused attention on UNCSTD and, through the international distribution of its SAREC-supported 'Lund letter', which chews over the problems that the conference will hopefully tackle, has stimulated discussion on the issues involved. Researchers at Lund agree with people at SAREC and those working on the national report: all stress the importance of preparatory work and discussion, which they hope will prevent UNCSTD from becoming a hugh jamborce with no coherent argumentation or follow-up.

The question of appropriate techno$\log y$ is also widely discussed. The national report goes out of its way to point out that, in a reaction to the belief that complicated technology will solve the Third World's problems, many people regard appropriate technology as essentially soft or simple. But, it stresses, technology that is suitable for a particular job in a particular country may be either simple or highly complex, depending on the capacity of the receiving country to use it and adapt it to its social and economic conditions. The question is complicated. because the degree of adaptation needed is not obvious and may by influenced by all sorts of factors. A survey of 15 large Swedish companies with international branches has shown that they have made only a few attempts to adapt their technology to suit the developing countries they operate in. This was said to be partly because some of the technology needed no modification, and partly hecause of the status-consciousness of some of the recipient countries.

Although the national report does not mention the fact. Sweden is one of the few UN members which contributes $1 \%$ of its gross national product in forcign aid. As a recent government statement points out, however, aid is only one part of trying to fulfil development goals. There is not much hope of alleviating the worst problems in many Third World countries until the price of raw materials has been stabilised, debts written off. and entrance assured to goods and capital markets. The Swedes are convinced that a similarly broad picture of the role of science and technology in development must be kept in focus if UNCSTD is going to make any difference at all to the two-thirds of the world's population in the developing countries.

\section{News from Orlov's trial}

\section{The Moscow Helsinki Monitoring Group put out this statement last week. It is based on Irina Orlova's account}

$66^{\circ}$

ORIOV's trial was a fiction. This is obvious from the fact that the authorities needed to detain him for 15 months in conditions of the strictest isolation in order to prepare the trial and only three days to examine the materials of the investigation in 58 volumes. The court needed no more than a few hours to discuss and draw up the sentence. ...

The formally open trial took place behind closed doors. Apart from specially selected people only Orlov's wife and two sons were allowed into the court room. Each time they were subjected to humiliating searches . Orlov's wife was stripped naked in the presence of men. Orlov's son was several times beaten on the head. Orlov's friends, including Academician Sakharov, were not allowed into the court room. . . .

In the course of the trial the Procurator and the court carefully avoided mention of the fact that the documents incriminating $\mathrm{Yu}$ Orlov are documents of the Moscow Helsinki Monitoring Group. The court established only the fact of Orlov's participation in the compilation of the documents and suppressed all attempts by Orlov and his counsel to examine the documents with regard to their content. That is, the court regarded all the documents in advance as "slanderous". . .

All appeals by Orlov and his counsel directed towards defending Orlov-the calling of witnesses for the defence, making known documents-were rejected by the court. Orlov's evidence was persistently and repeatedly interrupted by the court and his counsel's questions were struck out by the judge.

Realising that the advocate Ye S. Shalman could not carry out a political defence, Orlov, at the end of the judicial investigation, expressed gratitude to the counsel for his legal and moral help and renounced participation by the counsel in the cross examination, declaring that he himself would make the speech for the defence.

However, Orlov's speech for the defence was interrupted by numerous shouts from the judge and hostile cries from the specially selected audience.

The judge also interrupted the final speech. Orlov said: "Are you not ashamed to interrupt me, after all this is my last word?" However, even after this he was denied the chance to speak without interruption. Orlov was not allowed to complete either his speech for the defence or his final words.

After the court had granted the request that the counsel be relieved of any further participation in the case, the counsel, Ye S. Shalman, was removed by brute force from the court and was permitted to return only after he had telephoned the directors of the college of lawyers. ...

Therefore we affirm that the trial of Orlov was not an objective and just investigation but an attack on freedom of thought and speech.

The significance of the trial of Yurii Orlov, as well as that of political trials which have taken place in the past and those which are expected to take place in the near future of his friends in the Moscow Helsinki Group, the writer A. Ginsburg and the cybernetician A. Shcharansky, extends far beyond the horders of the USSR.

These trials have a direct relation not only with the question of human rights but also with that of detente in international relations.

We call upon the governments and heads of state of countries which signed the Helsinki Act, public organisations of those countries and private individuals, in the first place scientists and writers, to speak out in defence of Yurii Orlov, in defence of the Helsinki Act itself, which asserts an indissoluble link between the problem of security and human rights.

Members of the "Helsinki" Group: Y. Bonner, S. Kalistratova, M. Land, N. Meyman, V. Nekipelov, T. Osipova, V. Slepak. Member of the Georgian "Helsinki" Group: M. Goldshteyn.

We fully support the statement of the "Helsinki" Group about the trial of Professor Yu F. Orlov: A. Sakharov, I. Nudel, S. Polikanov, A. Lavut, A. Polikanov, I. Kovalev, Yu Yarym-Agayev, L. Kopelev, V. 99
Kornilov.

\section{The EEC reaction to the trial}

"The Nine, who consider that the Helsinki Final Act constitutes a programme of action for detente recall that, in this document signed by their heads of state or government, the participating states have committed themselves to respect human rights and fundamental freedoms and have confirmed the right of the individual to know and act upon his rights and duties in this field. . . The governments of the Nine find it incompatible with the Final Act and with detente that individuals should be prosecuted and sentenced for having demanded the implementation of the Final Act in their own country". 